\title{
A Contrast of Ethical Attitudes and Practices between Aviation Students at Schools With and Without an Ethics Course for Pilots
}

\author{
Ramón-Osvaldo González \\ Farmingdale State College \\ Richard Walter and Elsa-Sofia Morote \\ Dowling College
}

Author Note: This paper was adopted from: González, R.O. (2011). A measurement of ethical behavior of student pilots in u.s. higher education institutions and their affinity to abide by federal aviation regulations (Doctoral dissertation). Publication pending.

\begin{abstract}
The authors explore academic and ethical misconduct in various forms and consider the role of students' perceptions. They gather data from professional pilot students in four year academic disciplines from seven accredited universities across the United States. Four components are considered to better understand the behavior and perception of students' conduct in professional pilot education across the United States. These components are: attitude towards academic dishonesty, attitude towards neutralization behavior, attitude towards normalization of deviance, and ethical standards. Preliminary findings from the students' pre-tests are reported.
\end{abstract}

\section{INTRODUCTION}

Academic dishonesty among college students, reported to be at an all-time high, is a major concern of faculty members who teach aviation education. This type of student behavior is of particular interest since students' ethical behavior in college has been found to predict their ethical actions once in the workforce (Oderman, 2002). Oderman (2002) concluded in his study that ethics is an issue of concern in the aviation education community. Although many aviation accidents and problematic incidents can be attributed in whole or in part to unethical behavior or decision-making in some phase of the flight, most colleges and universities in the United States with a professional pilot program do not teach their students a formal ethics course. Ethics training has not been included as a structured part of most pilot aviation programs in higher education institutions. Professional pilot training is one of the largest areas of aviation education, but seems to have the least emphasis on structured ethical training for professional pilot students (Northam \& Diels, 2007). This study investigated professional pilot students' ethical behavior and their perception of ethics, academic misconduct, and ethical decision-making in the cockpit.

The public has the right to expect ethical behavior from aviation professionals, a behavior that will ensure the safety of their customers. This expectation is known as the Duty-of-Care, an implicit expectation of the public from companies offering public services. However, examples of unethical behavior from individuals and organizations are all too common. In April 2009, the Federal Aviation Administration (FAA) announced that Southwest Airlines had agreed to pay \$7.5M in fines for flying 46 aircraft on 59,791 flights without performing compulsory inspections for fuselage cracks. The aircraft, all Boeing 737s, carried an estimated 145,000 passengers without this important inspection ("Southwest to Pay,” 2009). In August 2008, the FAA charged American Airlines for deferred maintenance and other maintenance violations. The fine was $\$ 7.1 \mathrm{M}$ in civil penalties against the airline for improperly deferring maintenance on related equipment and deficiencies with its drug and alcohol testing programs and exit lighting inspections (Federal Aviation Administration, 2008).

America West Flight 556 was a regularly scheduled flight from Miami, Florida, to Phoenix, Arizona, 
operated by America West Airlines. On July 1, 2002, the plane was ordered back to the terminal after the pilots were suspected of being legally drunk. The pilots were ultimately convicted of operating an aircraft while intoxicated.

A former airline pilot was found guilty of flying under the influence of alcohol when he was secondin-command of a United Express flight. U.S. District Judge John Tunheim pronounced Aaron Cope guilty in a 15-page decision issued after a non-jury trial in Denver. Cope, 32, of Norfolk, Virginia, was co-pilot on the December 2009 flight from Austin to Denver of a regional jet with a 70-passenger capacity. "The court finds the evidence overwhelming that Cope was under the influence of alcohol during the flight," Tunheim wrote in the decisión (Boczkiewicz, 2011).

\section{SIGNIFICANCE OF THE STUDY}

A formal ethics course in the professional pilot curriculum may be a form of intervention in the process of changing students' behavior once in the workforce. Additionally, presenting an understanding as to what drives professional pilot students to violate federal aviation regulations will give aviation faculty an advantage to work toward the behavior modification of students. The result of this study may help aviation educators get a better understanding about aviation students' ethical behavior and their affinity to violate federal aviation regulations. With this understanding, faculties and department heads will be in a better position to update their curriculum and to implement formal courses of ethics.

\section{Research Question}

How do student pilots in higher education institutions, with and without formal ethics courses, describe their ethical standards, academic dishonesty, neutralization behavior, and normalization of deviance?

\section{LITERATURE REVIEW}

The increase in academic dishonesty in the classroom gained interest in the last several years with one specific study that demonstrated an increase of academic dishonesty among college students (Haines, Diekhoff, LaBoff, and Clark, 1986). Haines, et al., 1986, suggested that the literature on college dishonesty and cheating can be divided in two groups: those that study student personal characteristics which are predictive of higher level of academic dishonesty and those which analyze the situations or contextual factors that could lead to increased levels of academic dishonesty in different situations.

Leming (1980) concluded that "cheating behavior is a complex psychological, social, and situational phenomenon" (Leming, 1980, p.86). The Leming study was designed to relate cheating behavior to situational conditions and not to personal characteristics. The cheating was measured using the Hartshorne and May (1928) circle test, which does not bear a relationship to academic activities. This test was used to diminish the likelihood that anticipated academic success would be a factor in the students' cheating behavior. The test was administered under low risk and high risk conditions: a student could cheat by manipulating his/her own scores without the risk of detection (low risk situation), or a student could cheat under controlled conditions where no manipulation of the test scores would be possible without cheating being detected (high risk situation). This study revealed evidence that cheating is situation specific and the sanction of threats and high risk of detection can reduce the incidence of cheating.

The objective of Haines, Diekhoff, LaBoff, and Clark, (1986) in their study was to describe the incidence of cheating and further document its existence, to examine the occurrence of cheating from within the framework of Sykes and Matza's (1957) neutralization theory, to identify demographic as well 
as personal characteristics of students who cheat, and to search for the fundamental factors underlying cheating behavior. A 49 item survey was administered to 380 undergraduate students at a small southwest state university with a student population of 4,950. Eighty percent of the sample was overrepresented by freshmen and sophomore students. The survey contained items on demographic characteristics, incidence of cheating on major exams, quizzes, and class assignments, perceptions of and attitudes toward cheating by peers, and 11 items on a neutralization scale. The results showed that 54 percent of students reported cheating and only 1.3 percent reported ever been caught. This 1.3 percent can be related to Leming's (1980) study suggesting that a low risk condition existed. Demographic analysis demonstrated that cheaters tended to be younger, single, to have low GPA, and to be receiving financial support from sources other than self supporting. However, no significant differences were found in relation to gender or academic classification. Age showed to be the most significant correlation with cheating in all cheating categories, while lower GPA was second and lastly financial support. "When considered together, these variables can be used as a rough indication of the maturity and commitment to academics on the part of the student” (Leming, 1980, p. 350).

Haines, Diekhoff, LaBoff, and Clark (1986), found that neutralization is fundamental to cheating and can be best labeled as a common denominator in the cheating activities of students. A factor analysis of variables related to cheating was conducted, finding that 28.3 percent of the variance was represented by age, marital status, students' dependence upon parental financial support, and employment status. Haines, Diekhoff, LaBoff, and Clark (1986) concluded that students' immaturity, lack of commitment to academics, and lack of investment in their educations are among the underlying factors that affect students' academic dishonesty.

The McCabe and Travino (1997) study investigated both theories, Leming (1980) and Haines, Diekhoff, LaBoff, and Clark, (1986). This study was a multi-campus investigation on the individual and contextual construct. McCabe and Travino believed that the individual differences are that students have different predisposition to cheat. The study examined the relationship between academic dishonesty and age, gender, academic achievement, parents' education, and participation in extracurricular activities to demonstrate individual characteristics that can predict academic dishonesty. The major objective of this study was "to gain a comprehensive understanding of the relative effects on individual difference and contextual influences on academic dishonesty" (p. 385). McCabe and Travino were convinced, according to the studies of Bowers (1964) and McCabe and Travino (1993) that contextual factors had a strong influence on students' academic dishonesty and they believed these contextual factors, rather than individual differences, would have a greater influence on academic dishonesty.

One thousand seven hundred and ninety three students were surveyed, of which 65 percent were females. After the analysis of the data McCabe and Travino concluded that the findings supported the notion that academic dishonesty is affected by a variety of individual and contextual factors and are consistent with previous research (Bowers, 1964; McCabe and Trevino, 1993). The most powerful influential factors were peer related contextual factors. Twenty seven percent of the variance was accredited to contextual factors in self-reporting cheating when these variables were entered first into the hierarchical regression. However, even when the individual differences were entered first, a large portion of the variance was explained by the contextual variables. "Individual difference variables explained 9 percent while contextual variables explained 21 percent of the variance” (p. 391). From all the contextual variables, fraternity/sorority membership, peer behavior, and peer disapproval had the strongest impact in academic dishonesty.

One can suggest that academic dishonesty can be substantially reduced by implementing an honor code, as suggested by McCabe and Travino (1993). “The most important question to ask concerning academic dishonesty may be how an institution can create an environment where academic dishonesty is socially unacceptable, that is, where institutional expectations are clearly understood and where students 
perceive that their peers are adhering to these expectations” (McCabe and Travino, 1993, p. 534). McCabe and Travino (1993) studied the implementation of an honor code in institutions of higher education. The honor code is a system that transfers the responsibility of academic integrity from faculty and administrators to students. This process is accomplished by students taking ownership of such a code and consequently deeming academic dishonesty unacceptable by peers. McCabe and Travino's (1993) study was largely based on the social learning theory of Bandura (1986) suggesting that a large portion of human behavior would be learned by influence of example. Based on observation of a credible other, individuals will learn and change their behavior. In this case credible other means peer.

Academic dishonesty behavior, therefore, must be analyzed with insight on high and low risk environment (Leming, 1980), and individual and contextual constructs (McCabe and Travino, 1997).

Age: Typically, studies on college cheating concluded that that the younger the student, the higher the tendency of cheating (Haines, et. al. 1986). A twenty years follow up study was performed in 2007 where age was used as a discriminating variable, confirming that younger students cheat more than older students. This variable seems to be consistent with studies conducted from the late 1980s to more recent studies (Vandehey, Diekhoff, and LaBeff, 2007).

Gender: Unlike age, there are contradictory findings in past studies about gender. Most early researchers concluded that females cheat less than male students (Hetherington and Feldmen, 1964; Roskens and Dizney, 1966). McCabe and Travino reported in their 1997 study that male students cheat more than female students, however, the claim was made that contradicting reports were due to unique circumstances on individual campuses and therefore were driven by other factors (McCabe and Travino, 1997). Sex-Role socialization theory was used to explain the relationship between male and female students' cheating, arguing that female students were more likely than male students to be socialized to obey rules (Ward and Beck, 1990). Other studies explored this traditional gender difference and concluded insignificant differences between male and female student cheating (Baird, 1980; Lipson and McGavern, 1993). Two studies were found which reported a higher level of cheating in female students than male students (Leming, 1980; Antion and Michael, 1983). Lupton, Chapman, and Weiss, (2000) reported that female students will engage in cheating more freely when the risk of detection is reduced and when the threat of sanctions by a faculty member is at a minimum.

Cultural Identity: A major nationwide, multi-campus study was conducted in Taiwan to study the academic dishonesty of college students (Lin and Wen 2007). Lin and Wen found considerable differences between male and female students' practices of academic dishonesty; they found that male students exhibited higher tendency of cheating in exams and paper plagiarism than female students. This study showed that studies conducted in different geographical areas from European and Asian countries revealed the same amount of cheating in college students and was consistent with findings in the United States (Lin and Wen, 2007, p. 87). However, research showed that there are significant international differences in the students' attitude towards academic misconduct. Students' cultural identities may play a part in the tendency toward academic misconduct; therefore, the present study used cultural identity as a moderating variable. Magnus, Polterovich, Danilov, and Savvateev (2002) conducted a multi-nations study to analyze the tolerance of cheating across four countries: Russia, The Netherlands, Israel, and the United States. Their sample contained 885 students; 506 students from Russia, 112 from the United States, 247 from Netherlands, and 20 from Israel. The result showed that Russian students were more tolerant of cheating activities, condemning students who will act as informers and bringing academic dishonesty intensity to a high level. Students in the United States and the Netherlands were shown to be more concerned and willing to report academic dishonesty. "One would, therefore, expect that the higher the level of education, the less tolerant students were of the person who cheated” (p.128). 
Socioeconomic Status: Haines, Diekhoff, Labeff, and Clark's (1986) study showed that socioeconomic status will affect the students' commitment to education and advancement. Their analysis of the data demonstrated that students who have financial support from their parents tend to cheat at a higher rate than students who are financially self-supported.

Grade Point Average: Studies have been quite consistent when measuring academic dishonesty using grade point average or academic achievement as the independent variable (Hetherington and Feldmen, 1964; Roskens and Dizney, 1966; Baird, 1980; Lipson and McGavern, 1993; McCabe and Travino, 1997; and Vandehey, Diekhoff, and LaBeff, 2007). Leming presented a theoretical rationale for this phenomenon, claiming that students with a lower grade point average have less to lose and more to gain and therefore they tend to undertake the extra risks (Leming, 1980).

Parents' Level of Education: Parents' education as an indicator of academic dishonesty has been used less commonly than any other indicator in past studies. The children of a higher social class may be better prepared for higher education and have higher commitment to education and advancement (Bowers, 1964). Although Bowers' findings were that children from a higher social class are less likely to cheat, the relationship was very weak. Another study showed the opposite finding from Bowers' study, but also with a weak relationship (Kirkvliet, 1994)

The unethical conduct of some high profile companies attracted the attention of educators on decision-making ethics. The negative results of this behavior led some educators to the conclusion that ethical decision-making training must be emphasized within their curriculum (Northam and Diels, 2007). In the past few years, this conclusion has been echoed by educators in the aviation field and resulted in concern for including ethics training in many areas of aviation instruction (Oderman, 2002). Unethical behavior stories within the aviation industry are normal occurrences in our society. These stories appear regularly in the front page of newspapers and in other forms of media and there is evidence of unethical behavior in the early days of aviation.

Unethical behavior is not limited to the aviation industry. Each instance lessens the confidence of the public exponentially, whether it is in corporate business, medicine, the political arena, or public transport. The Ethics Officer \& Compliance Association reported in 1977 that nearly half of the workers in the United States had engaged in some unethical or illegal activities in the previous year (Oderman, 2002). Oderman (2002) concluded in his study that ethics is an issue of concern in the aviation education community.

\section{Conceptual Change Theory}

Many researchers describe misconception as a belief that is held contrary to known evidence. Misconception is mostly formed as the result of limited personal experiences, observations, or social interactions and inaccurate prior instructions. Many researchers refer to misconception as naïve psychological science to indicate that an individual will acquire these ideas in a primitive way through trial-and-error (Taylor \& Kowalski, 2004).

Conceptual change learning refers to the type of learning that occurs when the learner is introduced to new knowledge that is in conflict with earlier knowledge and must reorganize presented schemata and change formerly held ideas (Kowalski \& Taylor, 2004). This type of knowledge reorganization often works better with students who are able to engage in effortful processing, evaluating old beliefs and comparing them with new logical and more valuable concepts. Because this type of evaluation involves effort on the part of the learner, it is often more likely that the learner will choose to ignore or reject conflicting beliefs instead of reorganize his or her belief system (Chinn \& Brewer, 1993). As a result of this rejection by the learner, changing misconceptions is difficult and the learner will often leave the class 
with the same misconceptions with which he or she entered. This struggle to change is more evident in below-average learners, who might be less capable of understanding the new information, and in learners with low metacognitive skills, who might be unable to detect inconsistencies between the old and the new information (Dole \& Sinatra, 1988).

Researchers suggest that inconsistent prior knowledge makes it difficult for the learner to acquire a new concept. An assessment of the misconceptions the learner brings to class is essential for a teacher if the intent is to build on these misconceptions, building on these misconceptions will help the learner achieve sophisticated understandings and enables him or her to accept the new knowledge (Kowalski \& Taylor, 2004). Ninety freshman students volunteered to take part in a study by Taylor and Kowalski (2004), the researchers surveyed the participants at the start and end of an introductory psychology course using conceptual change learning theory as the treatment. The researcher concluded that the treatment was able to reduce the misconceptions of the learners by 30 percent.

\section{Ethics across the Curriculum}

All colleges teach ethics across the curricula, yet only few colleges make explicit attempt to coordinate the ethical lessons their students should be learning (Matchett, 2008; Oderman, 2002). Teaching ethics across the curriculum can be used as an alternative to implementing a dedicated ethics course in cases where there is simply no room for adding an additional course in the program of study. Teaching ethics across the curriculum can also be used for supporting and reinforcing material in the dedicated ethics course.

Does the knowledge of ethics and moral constructs affect behavior? This question has long been a topic of debate among educators, psychologists, and philosophers. There is agreement between researchers in various areas of study that there is a weak link between students' knowledge of ethics and moral constructs and ethical behavior. A student can know right from wrong and choose to act against his or her better judgment as a result of rationalization or the influence of his or her environment (Harris, 2008).

Ethics is covered in many disciplines in universities, as a required course or sometimes as an elective for other programs. Student's participation in ethics courses, for the purpose of changing behavior, does not offer the students the opportunity to evolve in their moral developments. Previous research indicated that the inclusion of ethics courses in a formal educational setting has little, if any, ethical behavior benefit. For ethics courses to have any effect on behavior they must be accompanied by role models (Gundersen, Capozzoli, \& Rajamma, 2008; Christensen \& Kohls, 2003; Goolsby \& Hunt, 1992; James, 2000; Kohlberg, 1969). Implementing ethics across the curriculum without having a dedicated ethics course might have an effect on ethical behavior (Ben-Jacob, 2005).

Disagreements between Greek philosophers on some aspects of knowledge of ethics and behavior were indicated by Irwin (1995); however, general agreement that the individual who is more knowledgeable on the subject of ethics tends to demonstrate more virtuous behavior was also noted. Socrates believed that having the right knowledge was all an individual would need to live a virtuous and good life. He supported the idea that one's behavior was an indicator of his or her knowledge about morality. Plato, on the other hand, believed that one's behavior indicated an inherent knowledge of virtue. Different from Socrates, Plato also believed that an individual must be exposed to appropriate behavior to possess knowledge of virtue and for moral education to have any effect on behavior, the behavioral model must come first (Irwin, 1995). Aronfreed (1978), a psychologist who conducted numerous studies about child development, concluded that behavior was partially controlled by conditions separate from rational thought. 
To offset the position that knowledge might not be a valid predictor of behavior, Rest (1979) conducted a study demonstrating that the number of years of formal education and the progressive ability to effectively confront moral dilemmas were strongly related. While this study was not able to show that formal education is a direct predictor of behavior, Rest claimed that the exposure to higher levels of education offered the students different models and methods of processing that have an effect on the students’ decision-making approach (Rest, 1979).

Jennings (1999) agreed with Aronfreed's (1978) study in his article "What happened to business schools?” stating that Master's in Business Administration (MBA) students are cynically resigned to participate in unethical business practices despite all their business ethics education. This attitude is attributed to the factors controlling the business environment of the 21st century. It is difficult to determine the long-term effects of an ethics course when only measuring the effects before and after the course. When measuring the results at the end of the course, there are mixed interpretations of ethical dilemmas by students. Gundersen, Capozzoli, and Rajamma (2008) conducted a study on the progression of students' ethical beliefs throughout their education. They concluded that circumstantial ethics experience has more of an effect on an individual's behavior than a conventional ethics class; the ethics class was not a direct predictor of students' behavior (Gundersen, Capozzoli, \& Rajamma, 2008). Too often, the study of ethics is presented to students in its philosophical context, but are we teaching the right things? In most colleges, the study of ethics is treated as an academic exercise with some professors going a step further by introducing ethical issues in their respective discipline. A better approach on the part of professors might be to take a stand and impart ethics, to teach the right behavior. Presently, the direction we need to go regarding ethics' education is clear; it is also clear that our present ethics' education is not aiming in that direction (Cavaliere, Mulvaney, \& Swerdlow, 2010).

Ethical education is not changing unethical behavior; this is evident when we read about all the business scandals in recent times (Cavaliere et al., 2010). While researchers agree that ethics education is not a direct predictor of ethical behavior, there is evidence that individuals who had been exposed to higher levels of ethics education are inclined to make higher-level ethical decisions. This supports the notion that ethical behavior can be influenced by exposing students to different types of ethical dilemmas and case studies (Rest \& Narvaez, 1994).

Ethics education and the effect on student behavior have been debated by researchers for four decades. Some researchers support the idea that as individuals progress through different levels of moral development (Kohlberg 1974), their ability to deal with ethical dilemmas will improve, thus changing their ethical behaviors. This process can be achieved through formal education (Christensen \& Kohls, 2003; Goolsby \& Hunt, 1992; James, 2000; Kohlberg, 1969; Cavaliere et al., 2010). Other researchers disagree, claiming that an academic course will not change the student's ethical behaviors because by the time the student reaches college he or she has already formed ethical standards and beliefs (Gundersen, Capozzoli, \& Rajamma, 2008; Cragg, 1997). Churchill (1982) suggested that the distinction between ethics and morals is the key of the trainability of ethics. Ethics can be taught as a rational reflection upon a choice of behaviors. Moral values are developed earlier in the individual's life and the trainability while attending college is questionable at best. Churchill's (1982) suggestion raises questions for those researchers claiming that ethics cannot be taught, because students' ethical behaviors are formed earlier in each individual's life.

\section{METHODOLOGY AND DATA COLLECTION}

\section{Participants}

The population for this study was limited to second year professional pilot students enrolled in aviation professional pilot four year degree programs at five accredited institutions of higher education 
within the United States. Two institutions with no formal ethics course in their curriculum and three institutions with a formal ethics course in their curriculum were selected. These five institutions were carefully chosen because of the similarity of courses within their program and the sequence of courses throughout the four years. It is necessary to clarify that an ethics course is not a required course by the Federal Aviation Administration for professional pilot training; therefore, it becomes optional for institutions. The expectation was to survey between 30 and 50 students from each institution totaling 150 to 250 participants. A total of 150 valid surveys were received and used for this study.

\section{Instrument}

The instrument used was designed to collect quantitative data. This instrument was developed for the purpose of measuring students' attitudes and behaviors toward academic dishonesty and ethical standards, and students' neutralization and normalization behaviors. Part I of the survey instrument was designed to gather demographic data from the participants: age, gender, grade point average, cultural identity, socioeconomic status, parents' level of education, and type of flight training. Part II of the survey instrument was structured with four subscales: attitude towards academic dishonesty, attitude towards neutralization behavior, attitude towards normalization of deviance, and ethical standards. Part II, section one, of the survey instrument contained 32 items using a six-point Likert scale. This section was designed to collect participants' data regarding neutralization behavior and normalization of deviance. The responses included: strongly disagree, disagree, slightly disagree, slightly agree, agree, and strongly agree. The response of strongly disagree holds a numerical value of one while the response of strongly agree holds a numerical value of six.

Part II, section two, of the survey instrument contained nine items using a five-point Likert scale. This section was designed to collect participants' data on academic dishonesty behavior and perception. The participant was given situations concerning academic conduct and was asked to answer in two subscales: (a) Have you engaged in the behavior since entering the aviation program? The response options included: never, seldom, sometimes, often, and very often. The response of 'never' holds a numerical value of one and the response of 'very often' holds a numerical value of five; (b) How honest do you consider this behavior to be? The response options included: honest, slightly honest, slightly dishonest, very dishonest, and extremely dishonest. The response of 'honest' holds a numerical value of one and 'extremely dishonest' holds a numerical value of five.

Part II, section three, of the survey instrument contained 12 items using a five-point Likert scale. This section was designed to collect participants' data on ethical standards behavior and perception. The participant was given ethical situations and was asked to answer in two subscales: (a) have you engaged in the following behavior since entering the aviation program? The responses options included; never, seldom, sometimes, often, and very often. The response of 'never' holds a numerical value of one while the response of 'very often' holds a numerical value of five: (b) how ethical do you consider this action to be? The responses options included: ethical, slightly ethical, slightly unethical, very unethical, and extremely unethical. The response of 'ethical' holds a numerical value of one while the response of 'extremely unethical' holds a numerical value of five.

\section{Validity of the Original Survey Instrument}

Content validity was obtained by using an expert panel composed of three full-time student pilots, one member of the full-time aviation faculty, and one professional with ethics expertise. The panel was given definitions of academic honesty, ethical behavior, neutralization behavior, and normalization of deviance. The survey instrument contained 53 total items for panel review. Seventeen items pertain to neutralization behavior, 15 items pertain to normalization of deviance, nine pertain to academic honesty, and 12 items pertain to ethical standards. The expert panel was asked to carefully read all items and 
categorize each of them in accordance with the definitions given; in addition, the panel was asked to comment on the clarity of the questions and statements. In order for an item to be included in the revised survey instrument, three out of the five panel members were required to accept it. The responses were reviewed and all questions in the revised survey were deemed clear and valid. The raw score of each subscale is presented in Table 1.

Table 1. Survey Instrument Raw Scale

\begin{tabular}{llll}
\hline Subscale & Item number & Total Items & Raw Score Range \\
\hline Ethical Standards & $42,43,44,45$, & 12 & $24-120$ \\
& $46,47,48,49$, & & \\
& $50,51,52,53$ & & \\
\hline Academic Honesty & $33,34,35,36$, & 9 & $18-90$ \\
& $37,38,39,40$, & & \\
& 41 & & \\
\hline Neutralization Behavior & $2,3,5,7,8$, & 17 & $17-153$ \\
& $10,13,15,17$, & & \\
& $20,21,24,26$, & & \\
& $27,28,29,31$ & & \\
\hline Normalization of Deviance & $1,4,6,9,11$, & 15 & \\
& $12,14,16,18$, & & \\
$19,22,23,25$, & & \\
& 30,32 & & \\
\end{tabular}

\section{Factor Analysis}

Fifty-three items on the survey instrument were subjected to factor analysis utilizing 150 usable responses to obtain discrete subscales. To determine the number of factors to retain, the Kaizer-Guttman rule was first applied, followed by the Cattell's scree test. The Kaizer-Guttman rule was applied to define all factors with eigenvalues greater than one. It was followed by the Cattell's scree test to examine the magnitude of changes in eigenvalues from one factor to another. The dimensionality of the 150 usable responses was analyzed using principle component factor analysis. The result of the Kaizer-Guttman revealed 15 components with an eigenvalue greater than one. Analysis of the Cattell's scree clearly showed six factors with significant changes between eigenvalues, which was confirmed by the scree plot from the extraction process where a clear break showed after the sixth subscale. The six discrete subscales accounted for 61.91 percent of the variance. Based on these analyses, six factors were rotated using a Varimax rotation procedure. The rotation solution yielded six interpretable factors: Ethical Conduct (EC), Ethical Beliefs (EB), Academic Conduct (AC), Academic Honesty Belief (AHB), Neutralization Behavior (NB), and Normalizations of Deviance (ND).

Thirteen items loaded in more than one dimension. Item 25 loaded for both, Neutralization Behavior (NB) and Normalization of Deviance (ND). Item 51a loaded for both Neutralization Behavior (NB) and Ethical Conduct (EC). Items 34a, 47a, 48a, 36a, 35a, and 40a loaded for both Ethical Conduct (EC) and Academic Honesty Beliefs (AHB). Items 33b, 34b, 35b, 36b, 37b, 40b, and 41b loaded for both, Ethical Beliefs (EB) and Academic Honesty Beliefs (AHB). An attempt was made to use Varimax as a rotation method to investigate whether these items would be associated with an additional dimension. The attempt showed no other dimension for these items. After a reliability test was performed on individual variables, the items were retained based on factor analysis loading showing significant differences between factor loading and the reliability test showing no significant difference in the Cronbach's Alpha by keeping the 
items as part of the variable. Items 28, 41a, and 53a did not load in any factors and were consequently deleted from the analysis.

Table 2 indicates the distribution of the 71 items that were retained for this study as a result of the factor analysis, alpha coefficient, and raw score range of each of the six variables.

Table 2. Scale Reliability Resulting from Factor Analysis

\begin{tabular}{|c|c|c|c|c|}
\hline Subscale & $\begin{array}{l}\text { Items } \\
\text { Number }\end{array}$ & Total Items & Range of Scores & $\alpha$ \\
\hline Ethical Conduct (EC) & $\begin{array}{l}\text { 42a, 43a, 44a, 45a, } \\
\text { 46a, 47a, 48a, 49a, } \\
\text { 50a, 51a, 52a }\end{array}$ & 11 & $11-55$ & .893 \\
\hline Ethical Beliefs (EB) & $\begin{array}{l}\text { 42b, 43b, 44b, 45b, } \\
\text { 46b, 47b, 48b, 49b, } \\
\text { 50b, 51b, 52b, 53b }\end{array}$ & 12 & $12-60$ & .955 \\
\hline Academic Conduct (AC) & $\begin{array}{l}\text { 33a, 34a, 35a, 36a, } \\
\text { 37a, 38a, 39a, 40a }\end{array}$ & 8 & $8-40$ & .849 \\
\hline Academic Honesty Beliefs (AHB) & $\begin{array}{l}\text { 33b, 34b, 35b, 36b, } \\
\text { 37b, 38b, 39b, 40b, } \\
41 b\end{array}$ & 9 & $9-45$ & .958 \\
\hline Neutralization Behavior(NB) & $\begin{array}{l}2,3,5,7,8,10,13, \\
15,17,20,21,24, \\
26,27,29,31\end{array}$ & 16 & $16-96$ & .924 \\
\hline Normalization of Deviance (ND) & $\begin{array}{l}1,4,6,9,11,12,14, \\
16,18,19,22,23, \\
25,30,32\end{array}$ & 15 & $15-90$ & .896 \\
\hline
\end{tabular}

After factor analysis, the research question was revised to reflect all six factors names.

\section{Revised Research Question}

How do student pilots in higher education institutions, with and without formal ethics courses, describe their Ethical Conduct (EC), Ethical Beliefs (EB), Academic Conduct (AC), Academic Honesty Beliefs (AHB), Neutralization Behavior (NB), and Normalization of Deviance (ND)?

The research question was answered using $t$-test and descriptive statistics, means, SD, and frequencies to analyze results.

\section{DATA ANAL YSIS}

Preliminary information about the respondents is presented here. Sixty nine and one half percent of the respondents were Caucasian/white, 13.6\% identify themselves as Hispanic/Latino, 5.2\% Asian, and 9.1\% African-American/Black. Table 3 shows student participants GPA. The majority of the students reported their score to be between 3.0 and 3.5 (51.5\%), followed by $32.1 \%$ of students reporting GPA scores between 3.6 and 4.0 .

Table 4 shows the type of flight training of the students participating in the survey. Student flight training is regulated by the Federal Aviation Administration. Students take their training under one of the two types of course structure designated by the FAA; 14§CFR61 Subpart E through F or 14§CFR141 
Appendices B through D. Curriculums under 14§CFR141 Appendices B through D are overseen by the FAA and are more rigorous then curriculums under 14§CFR61 Subpart E through F.

Table 3. Students’ Grade Point Average

\begin{tabular}{lcccc}
\hline \multicolumn{1}{c}{ GPA } & Frequency & Percent & Valid Percent & $\begin{array}{c}\text { Cumulative } \\
\text { Percent }\end{array}$ \\
\hline 2.0 to 2.5 & 5 & 3.2 & 3.7 & 3.7 \\
2.6 to 2.9 & 17 & 11.0 & 12.7 & 16.4 \\
3.0 to 3.5 & 69 & 44.5 & 51.5 & 77.9 \\
3.6 to 4.0 & 43 & 27.7 & 32.1 & 100.0 \\
Total & 134 & 86.5 & 100.0 & \\
Missing & 21 & 13.5 & & \\
\hline Valid N & Valid N & 155 & 100.0 & \\
\hline
\end{tabular}

Table 4. Students' Type of Flight Training

\begin{tabular}{lcccc}
\hline & Frequency & Percent & Valid Percent & Cumulative \\
\hline 14§CFR61 & 24 & 15.5 & 19.5 & 19.5 \\
14§CFR141 & 99 & 63.9 & 80.5 & 100.0 \\
Total & 123 & 79.4 & 100.0 & \\
Missing & 32 & 20.6 & & \\
\hline Valid N & Valid N & 155 & 100.0 & \\
\hline
\end{tabular}

Table 5 shows students' cultural identity. Most students indicated their cultural identity to be American (77.4\%) with 22.6\% reporting other cultural identities.

Table 5. Students’ Cultural Identity

\begin{tabular}{lcccc}
\hline & Frequency & Percent & Valid Percent & Cumulative Percent \\
\hline U.S.A. & 120 & 77.4 & 77.4 & 77.4 \\
Latin American & 9 & 5.8 & 5.8 & 83.2 \\
Caribbean & 4 & 2.6 & 2.6 & 95.8 \\
Western European & 12 & 7.7 & 7.7 & 93.5 \\
African & 3 & 1.9 & 1.9 & 95.5 \\
Asian & 4 & 2.6 & 2.6 & 98.1 \\
Eastern European & 3 & 1.9 & 1.9 & 100.0 \\
\hline Total & 155 & 100.0 & 100.0 & \\
\hline
\end{tabular}

\section{RESEARCH QUESTION}

How do student pilots in higher education institutions, with and without formal ethics courses, describe their Ethical Conduct (EC), Ethical Beliefs (EB), Academic Conduct (AC), Academic Honesty Beliefs (AHB), Neutralization Behavior (NB), and Normalization of Deviance (ND)?

The research question investigated the students' self-reported ethical conduct and beliefs, their academic conduct and academic dishonesty beliefs, their attitude towards neutralization behavior, and their attitude toward normalization of deviance. For this analysis, $t$-test and descriptive statistics were 
used in order to generate the frequency of student engagement in these behaviors and to represent the differences, if any, between the two groups.

Eleven questions were selected to measure the participant's ethical conduct. Descriptive statistics were used to generate the frequency of student engagement in unethical behaviors. Survey responses were scored using $1=$ Very Often, 2=Often, $3=$ Sometimes, 4=Seldom, and $5=$ Never. The mean score for frequency of student engagement in unethical behavior, with a range of 11 to 55, was 54.06 for students enrolled in institutions with mandatory ethics course in their curriculum. The mean score for frequency of student engagement in unethical behavior, with a range of 11 to 55, was 53.60 for students enrolled in institutions without mandatory ethics course. The data indicate that as a group, students enrolled in institutions with mandatory ethics course tend to engage less frequently in unethical behaviors.

Table 6 reports the number of responses, the mean, standard deviation, and number of items for both, students enrolled in institutions with mandatory ethics course and students enrolled in institutions without mandatory ethics course. Table 7 reports the result of the $t$-test.

Table 6. Mean and Standard Deviation for Ethical Conduct

\begin{tabular}{lcccc}
\hline School with Ethics Course & N & M & SD & Number of Items \\
\hline Ethical Conduct & 81 & 54.06 & 2.71 & 11 \\
\hline Valid N (listwise) & 81 & & & \\
\hline School without Ethics s Course & $\mathrm{N}$ & $\mathrm{M}$ & $\mathrm{SD}$ & Number of Items \\
\hline Ethical Conduct & 68 & 53.60 & 2.84 & 11 \\
\hline Valid N (listwise) & 68 & & & \\
\hline
\end{tabular}

Table 7. $t$-test Ethical Conduct (EC)

\begin{tabular}{lcccccccc}
\hline School Code & $\mathrm{N}$ & $\mathrm{M}$ & $\mathrm{SD}$ & $\mathrm{SDE}$ & $\mathrm{t}$ & $\mathrm{df}$ & $\rho$ & Mean \\
\hline Ethics Course & 81 & 54.06 & 2.71 & 0.20 & 1.00 & 147 & 0.31 & 0.46 \\
No Ethics Course & 68 & 53.60 & 2.84 & 0.36 & & & & \\
\hline
\end{tabular}

Descriptive statistics were performed to analyze the frequency of students' engagement in each of the eleven behaviors. Table 8 reports the frequency of student engagement in specific unethical behavior. Twelve questions were selected to measure the participants' ethical beliefs. Descriptive statistics were used to generate the frequency of student unethical beliefs. Survey responses were scored using 1=Ethical, 2=Slightly ethical, 3=Slightly unethical 4=Very unethical, and 5=Extremely unethical.

The mean score for frequency of student ethical beliefs, with a range of 36 to 60, was 51.20 for students enrolled in institutions with mandatory ethics course in their curriculum. The mean score for frequency of student ethical beliefs, with a range of 31 to 60, was 52.37 for students enrolled in institutions without mandatory ethics course in their curriculum. The data indicate that as a group, students enrolled in an institution without a mandatory ethics course perceive these behaviors to be very unethical while students enrolled in institutions with an ethics course perceive this action to be slightly more acceptable than that of the first group. 
Table 8. Frequency of student engagement in specific unethical behaviors

\begin{tabular}{|c|c|c|c|c|c|c|}
\hline & \multicolumn{3}{|c|}{ School With Ethics Course } & \multicolumn{3}{|c|}{ School Without Ethics Course } \\
\hline & $\mathrm{N}$ & $\mathrm{S}+\mathrm{ST}$ & $\mathrm{O}+\mathrm{VO}$ & $\mathrm{N}$ & $\mathrm{S}+\mathrm{ST}$ & $\mathrm{O}+\mathrm{VO}$ \\
\hline $\begin{array}{l}\text { Coming to the airport and providing } \\
\text { services to passengers, on the ground or in } \\
\text { the air, under the influence of drugs, } \\
\text { including alcohol. }\end{array}$ & $97.6 \%$ & $2.4 \%$ & $0.0 \%$ & $94.4 \%$ & $4.2 \%$ & $1.4 \%$ \\
\hline $\begin{array}{l}\text { Not reporting an incident that involves } \\
\text { passengers. }\end{array}$ & $98.8 \%$ & $0.0 \%$ & $1.2 \%$ & $98.6 \%$ & $0.0 \%$ & $1.4 \%$ \\
\hline Recording flight time that was not flown. & $95.2 \%$ & $3.6 \%$ & $1.2 \%$ & $95.7 \%$ & $2.8 \%$ & $1.5 \%$ \\
\hline $\begin{array}{l}\text { Reporting and/or recording flight } \\
\text { procedures when it was not performed. }\end{array}$ & $95.2 \%$ & $3.6 \%$ & $1.2 \%$ & $95.7 \%$ & $2.8 \%$ & $1.5 \%$ \\
\hline $\begin{array}{l}\text { Inaccurate recording or reporting aircraft } \\
\text { discrepancies. }\end{array}$ & $92.8 \%$ & $7.2 \%$ & $0.0 \%$ & $95.7 \%$ & $4.3 \%$ & $0.0 \%$ \\
\hline $\begin{array}{l}\text { Reporting weather phenomenon that was } \\
\text { not observed or recalled accurately. }\end{array}$ & $94.0 \%$ & $6.0 \%$ & $0.0 \%$ & $91.3 \%$ & $8.7 \%$ & $0.0 \%$ \\
\hline $\begin{array}{l}\text { Attempting to perform a procedure in } \\
\text { which you are not competent or current } \\
\text { without the assistance of a Certified Flight } \\
\text { Instructor. }\end{array}$ & $88.1 \%$ & $10.7 \%$ & $1.2 \%$ & $85.7 \%$ & $14.3 \%$ & $0.0 \%$ \\
\hline $\begin{array}{l}\text { Contaminating the environment, } \\
\text { intentionally or by accident and not } \\
\text { reporting it to the proper authority. }\end{array}$ & $91.7 \%$ & $8.3 \%$ & $0.0 \%$ & $85.9 \%$ & $11.3 \%$ & $2.8 \%$ \\
\hline $\begin{array}{l}\text { Losing, breaking, or damaging passengers' } \\
\text { belongings and not reporting it. }\end{array}$ & $96.4 \%$ & $3.6 \%$ & $0.0 \%$ & $94.3 \%$ & $5.7 \%$ & $0.0 \%$ \\
\hline $\begin{array}{l}\text { Reporting inaccurately to a passenger the } \\
\text { cause of a delay in a flight. }\end{array}$ & $88.0 \%$ & $12.0 \%$ & $0.0 \%$ & $85.5 \%$ & $14.5 \%$ & $0.0 \%$ \\
\hline $\begin{array}{l}\text { Reporting operational problems with an } \\
\text { aircraft inaccurately. }\end{array}$ & $96.4 \%$ & $3.6 \%$ & $0.0 \%$ & $91.4 \%$ & $5.7 \%$ & $2.9 \%$ \\
\hline
\end{tabular}

$N=$ Never, $S=$ Seldom, $S T=$ Sometimes, $O=$ Often, $V O=$ Very Often

Table 9 reports the number of responses, the mean, standard deviation, and number of items for both students enrolled in institutions with mandatory ethics course and students enrolled in institutions without mandatory ethics course and Table 10 represents the result of the $t$-test. Table 11 reports the frequency of student answers on ethical beliefs.

Table 9. Mean and Standard Deviation for Ethical Beliefs

\begin{tabular}{lcccc}
\hline School with Ethics Course & N & M & SD & Number of Items \\
\hline Ethical Beliefs & 77 & 51.20 & 8.34 & 12 \\
\hline Valid N (listwise) & 77 & & & \\
\hline School without Ethics Course & N & M & SD & Number of Items \\
\hline Ethical Beliefs & 69 & 52.37 & 7.02 & 12 \\
\hline Valid N (listwise) & 69 & & & \\
\hline
\end{tabular}


Table 10. t-test Ethical Beliefs (EB)

\begin{tabular}{lcccccccc}
\hline School Code & $\mathrm{N}$ & $\mathrm{M}$ & $\mathrm{SD}$ & $\mathrm{SDE}$ & $\mathrm{t}$ & $\mathrm{df}$ & $\rho$ & Mean Difference \\
\hline Ethics Course & 77 & 51.19 & 8.34 & 0.96 & -0.92 & 144 & 0.36 & -1.18 \\
No Ethics Course & 69 & 52.38 & 7.02 & 0.86 & & & & \\
\hline
\end{tabular}

Table 11: Frequency of students’ Ethical Beliefs

\begin{tabular}{|c|c|c|c|c|c|c|}
\hline & \multicolumn{3}{|c|}{ School With Ethics Course } & \multicolumn{3}{|c|}{$\begin{array}{l}\text { School Without Ethics } \\
\text { Course }\end{array}$} \\
\hline & $\mathrm{E}+\mathrm{SE}$ & SU & $\mathrm{VU}+\mathrm{EU}$ & $\mathrm{E}+\mathrm{SE}$ & SU & $\begin{array}{c}\mathrm{VU}+\mathrm{E} \\
\mathrm{U}\end{array}$ \\
\hline $\begin{array}{l}\text { Coming to the airport and providing } \\
\text { services to passengers, on the ground or } \\
\text { in the air, under the influence of drugs, } \\
\text { including alcohol. }\end{array}$ & $1.2 \%$ & $15.9 \%$ & $82.9 \%$ & $2.8 \%$ & $1.4 \%$ & $95.8 \%$ \\
\hline $\begin{array}{l}\text { Not reporting an incident that involves } \\
\text { passengers. }\end{array}$ & $0.0 \%$ & $19.4 \%$ & $80.6 \%$ & $1.4 \%$ & $5.6 \%$ & $93.0 \%$ \\
\hline $\begin{array}{l}\text { Recording flight time that was not } \\
\text { flown. }\end{array}$ & $1.2 \%$ & $19.5 \%$ & $79.3 \%$ & $0.0 \%$ & $11.3 \%$ & $88.7 \%$ \\
\hline $\begin{array}{l}\text { Reporting and/or recording flight } \\
\text { procedures when it was not performed. }\end{array}$ & $0.0 \%$ & $22.2 \%$ & $77.8 \%$ & $1.4 \%$ & $16.9 \%$ & $81.7 \%$ \\
\hline $\begin{array}{l}\text { Inaccurate recording or reporting aircraft } \\
\text { discrepancies. }\end{array}$ & $0.0 \%$ & $23.2 \%$ & $76.8 \%$ & $1.4 \%$ & $15.5 \%$ & $83.1 \%$ \\
\hline $\begin{array}{l}\text { Reporting weather phenomenon that was } \\
\text { not observe or recalled accurately. }\end{array}$ & $2.4 \%$ & $29.3 \%$ & $68.3 \%$ & $7.1 \%$ & $19.7 \%$ & $73.2 \%$ \\
\hline $\begin{array}{l}\text { Attempting to perform a procedure in } \\
\text { which you are not competent or current } \\
\text { without the assistance of a Certified } \\
\text { Flight Instructor. }\end{array}$ & $3.7 \%$ & $30.9 \%$ & $65.4 \%$ & $2.8 \%$ & $26.8 \%$ & $70.4 \%$ \\
\hline $\begin{array}{l}\text { Contaminating the environment, } \\
\text { intentionally or by accident and not } \\
\text { reporting it to the proper authority. }\end{array}$ & $0.0 \%$ & $22.0 \%$ & $78.0 \%$ & $2.8 \%$ & $15.5 \%$ & $81.7 \%$ \\
\hline $\begin{array}{l}\text { Losing, breaking, or damaging } \\
\text { passengers' belongings and not reporting } \\
\text { it. }\end{array}$ & $0.0 \%$ & $17.1 \%$ & $82.9 \%$ & $2.8 \%$ & $12.7 \%$ & $84.5 \%$ \\
\hline $\begin{array}{l}\text { Reporting inaccurately to a passenger } \\
\text { the cause of a delay in a flight. }\end{array}$ & $4.9 \%$ & $30.9 \%$ & $64.2 \%$ & $10.2 \%$ & $21.7 \%$ & $68.1 \%$ \\
\hline $\begin{array}{l}\text { Reporting operational problems with an } \\
\text { aircraft inaccurately. }\end{array}$ & $0.0 \%$ & $17.3 \%$ & $82.7 \%$ & $4.1 \%$ & $9.9 \%$ & $86.0 \%$ \\
\hline $\begin{array}{l}\text { Not reporting any physical or health } \\
\text { related change that may delimit my } \\
\text { flying capacity. }\end{array}$ & $2.4 \%$ & $18.3 \%$ & $79.3 \%$ & $11.3 \%$ & $11.3 \%$ & $77.5 \%$ \\
\hline
\end{tabular}

$E=$ Ethical, $S E=$ Slightly Ethical, $S U=$ Slightly Unethical, $V U=$ Very Unethical, EU=Extremely

Unethical

Eight questions were selected to measure the participants' academic conduct, survey responses were scored using a five point liker scale ranging from 1 ) $=$ Very often, 2 ) $=$ Often, 3 ) $=$ Sometimes, 4$)=$ 
Seldom, and 5)= Never. A score of five represents excellent academic conduct while a score of one represents extremely weak academic conduct.

The mean score for frequency of student academic conduct, with a range of 31 to 40, was 38.10 for students enrolled in institutions with mandatory ethics course in their curriculum. The mean score for frequency of student academic conduct, with a range of 30 to 40, was 37.60 for students enrolled in institutions without mandatory ethics course in their curriculum. The data shows that the academic conduct of these two groups of students is very similar. As a group, they reported never or seldom engaging in academic dishonesty activities.

Table 12 reports the number of responses, the mean frequency of student academic conduct, the standard deviation, and the number of items. Table 13 represents the results of the $t$-test. Table 14 reports the frequency of student specific behavior of academic conduct.

Table 12. Mean and Standard Deviation for Academic Conduct

\begin{tabular}{lcccc}
\hline School with Ethics Course & N & M & SD & Number of Items \\
\hline Academic Conduct & 79 & 38.10 & 2.48 & 8 \\
\hline Valid N & 79 & & & \\
\hline School without Ethics Course & N & M & SD & Number of Items \\
\hline Academic Conduct & 68 & 37.60 & 2.86 & 8 \\
\hline Valid N & 68 & & & \\
\hline
\end{tabular}

Table 13: Academic Conduct (AC)

\begin{tabular}{lllllllll}
\hline School Code & $\mathrm{N}$ & $\mathrm{M}$ & $\mathrm{SD}$ & $\mathrm{SDE}$ & $\mathrm{t}$ & $\mathrm{df}$ & $\rho$ & Mean Difference \\
\hline Ethic Course & 79 & 38.10 & 2.48 & 0.27 & 1.13 & 145 & 0.26 & 0.50 \\
No Ethic & 68 & 37.60 & 2.86 & 0.34 & & & & \\
\hline
\end{tabular}

Nine questions were selected to measure the participants' academic dishonesty beliefs, survey responses were scored using a five point liker scale ranging from 1) $=$ Honest, 2) $=$ Slightly honest, 3) $=$ Slightly dishonest, 4) Very dishonest, and 5) Extremely dishonest. A score of five represents a good understanding of academic dishonesty while a score of one represents a misunderstanding of academic dishonesty.

The mean score for frequency of students' academic dishonesty beliefs, with a range of 23 to 45, was 37.41 for students enrolled in institutions with mandatory ethics course in their curriculum. The mean score for frequency of students' academic dishonesty beliefs, with a range of 25 to 45, was 37.00 for students enrolled in institutions without a mandatory ethics course in their curriculum. The data shows that as a group, they reported having a good understanding about academic dishonesty. 
Table 14. Frequency of student engagement on specific behaviors of Academic Conduct

\begin{tabular}{l|c|c|c|c|c|c|}
\hline & \multicolumn{2}{|c|}{ School With Ethics Course } & \multicolumn{3}{|c|}{ School Without Ethics } \\
\cline { 2 - 7 } & $\mathrm{N}$ & $\mathrm{S}+\mathrm{ST}$ & $\mathrm{O}+\mathrm{VO}$ & $\mathrm{N}$ & $\mathrm{S}+\mathrm{ST}$ & $\mathrm{O}+\mathrm{VO}$ \\
\hline $\begin{array}{l}\text { Getting test questions from another pilot } \\
\text { student who has taken the exam or quiz at } \\
\text { an earlier time. }\end{array}$ & $69.1 \%$ & $29.7 \%$ & $1.2 \%$ & $74.6 \%$ & $23.9 \%$ & $1.5 \%$ \\
\hline $\begin{array}{l}\text { Copying from another pilot student's test } \\
\text { without their knowledge. }\end{array}$ & $91.6 \%$ & $8.4 \%$ & $0.0 \%$ & $91.4 \%$ & $8.6 \%$ & $0.0 \%$ \\
\hline $\begin{array}{l}\text { Copying from another pilot student's test } \\
\text { with their knowledge. }\end{array}$ & $86.9 \%$ & $13.1 \%$ & $0.0 \%$ & $88.7 \%$ & $11.3 \%$ & $0.0 \%$ \\
\hline $\begin{array}{l}\text { Receiving answers from another pilot } \\
\text { student during a test. }\end{array}$ & $88.0 \%$ & $12.0 \%$ & $0.0 \%$ & $85.9 \%$ & $14.1 \%$ & $0.0 \%$ \\
\hline $\begin{array}{l}\text { Allowing a pilot student to copy answers } \\
\text { from you during a test. }\end{array}$ & $81.0 \%$ & $19.0 \%$ & $0.0 \%$ & $79.7 \%$ & $20.3 \%$ & $0.0 \%$ \\
\hline $\begin{array}{l}\text { Using notes, books, cell phones etc. during } \\
\text { a closed book test to gain answers. }\end{array}$ & $88.0 \%$ & $12.0 \%$ & $0.0 \%$ & $80.0 \%$ & $20.0 \%$ & $0.0 \%$ \\
\hline $\begin{array}{l}\text { Paraphrasing or copying material from } \\
\text { another source without referencing the } \\
\text { source. }\end{array}$ & $66.3 \%$ & $33.7 \%$ & $0.0 \%$ & $60.9 \%$ & $37.7 \%$ & $1.4 \%$ \\
\hline $\begin{array}{l}\text { Working with another student on an out of } \\
\text { class assignment when not allowed by the } \\
\text { instructor. }\end{array}$ & $65.4 \%$ & $32.1 \%$ & $2.5 \%$ & $68.6 \%$ & $27.1 \%$ & $4.3 \%$ \\
\hline
\end{tabular}

$N=$ Never,$S=$ Seldom, $S T=$ Sometimes, $O=O f t e n, V O=$ Very $O f t e n$

Table 15 reports the number of responses, the mean frequency of students' academic dishonesty beliefs, the standard deviation, and the number of items. Table 16 reports the result of the $t$-test. Table 17 reports the frequency of students' specific behaviors representing academic dishonesty beliefs.

Table 15. Means and Standard Deviation for Academic Dishonesty Beliefs

\begin{tabular}{lcccc}
\hline School with Ethics Course & N & M & SD & Number of Items \\
\hline Academic Dishonesty Beliefs & 81 & 37.41 & 6.77 & 9 \\
\hline Valid N & 81 & & & \\
\hline School without Ethics Course & N & M & SD & Number of Items \\
\hline Academic Dishonesty Beliefs & 63 & 37.00 & 6.15 & 9 \\
\hline Valid N & 63 & & & \\
\hline
\end{tabular}

Table 16. t-test Academic Dishonesty Beliefs (ADB)

\begin{tabular}{lllllllll} 
School Code & $\mathrm{N}$ & $\mathrm{M}$ & $\mathrm{SD}$ & $\mathrm{SDE}$ & $\mathrm{t}$ & $\mathrm{df}$ & $\rho$ & Mean Difference \\
Ethic Course & 81 & 37.41 & 6.77 & 0.76 & 0.37 & 142 & 0.71 & 0.41 \\
No Ethic Course & 63 & 37.00 & 6.15 & 0.80 & & & & \\
\hline
\end{tabular}


Table 17. Frequency of students' academic dishonesty beliefs

\begin{tabular}{|c|c|c|c|c|c|c|}
\hline \multirow[b]{3}{*}{$\begin{array}{l}\text { Getting test questions from another pilot } \\
\text { student who has taken the exam or quiz } \\
\text { at an earlier time. }\end{array}$} & \multicolumn{3}{|c|}{ School With Ethics Course } & \multicolumn{3}{|c|}{$\begin{array}{l}\text { School Without Ethics } \\
\text { Course }\end{array}$} \\
\hline & $\mathrm{H}+\mathrm{SH}$ & SD & $\mathrm{VD}+\mathrm{ED}$ & $\mathrm{H}+\mathrm{SH}$ & SD & $\begin{array}{l}\mathrm{VD}+\mathrm{E} \\
\mathrm{D}\end{array}$ \\
\hline & $8.3 \%$ & $32.1 \%$ & $59.6 \%$ & $4.3 \%$ & $34.3 \%$ & $61.4 \%$ \\
\hline $\begin{array}{l}\text { Copying from another pilot students' } \\
\text { test without their knowledge. }\end{array}$ & $0.0 \%$ & $13.1 \%$ & $86.9 \%$ & $1.4 \%$ & $8.5 \%$ & $90.1 \%$ \\
\hline $\begin{array}{l}\text { Copying from another pilot students' } \\
\text { test with their knowledge. }\end{array}$ & $1.2 \%$ & $25.0 \%$ & $73.8 \%$ & $2.9 \%$ & $14.3 \%$ & $82.8 \%$ \\
\hline $\begin{array}{l}\text { Receiving answers from another pilot } \\
\text { student during a test. }\end{array}$ & $3.6 \%$ & $25.0 \%$ & $71.4 \%$ & $0.0 \%$ & $15.9 \%$ & $84.1 \%$ \\
\hline $\begin{array}{l}\text { Allowing a pilot student to copy answers } \\
\text { from you during a test. }\end{array}$ & $1.2 \%$ & $26.2 \%$ & $72.6 \%$ & $5.6 \%$ & $16.9 \%$ & $77.5 \%$ \\
\hline $\begin{array}{l}\text { Using notes, books, cell phones etc. } \\
\text { during a closed book test to gain } \\
\text { answers. }\end{array}$ & $0.0 \%$ & $20.5 \%$ & $79.5 \%$ & $0.0 \%$ & $20.0 \%$ & $80.0 \%$ \\
\hline $\begin{array}{l}\text { Paraphrasing or copying material from } \\
\text { another source without referencing the } \\
\text { source. }\end{array}$ & $1.2 \%$ & $36.1 \%$ & $62.7 \%$ & $2.8 \%$ & $28.2 \%$ & $69.0 \%$ \\
\hline $\begin{array}{l}\text { Working with another student on an out } \\
\text { of class assignment when not allowed by } \\
\text { the instructor. }\end{array}$ & $2.5 \%$ & $39.5 \%$ & $58.0 \%$ & $12.9 \%$ & $34.3 \%$ & $52.8 \%$ \\
\hline $\begin{array}{l}\text { Developing a personal relationship with } \\
\text { the aviation professor to gain } \\
\text { information about the test. }\end{array}$ & $13.2 \%$ & $26.5 \%$ & $60.3 \%$ & $10.5 \%$ & $26.9 \%$ & $62.6 \%$ \\
\hline
\end{tabular}

$\mathrm{H}=$ Honest, $\mathrm{SH}=$ Slightly honest, $\mathrm{SD}=$ Slightly dishonest, $\mathrm{VD}=$ Very dishonest, $\mathrm{ED}=$ Extremely dishonest

Sixteen questions were selected to measure the participant's neutralization behavior, survey responses were scored using a six point Likert scale ranging from 1) Strongly disagree, 2) Disagree, 3) Slightly disagree, 4) Slightly agree, 5) Agree, to 6) Strongly agree. A score of one defined a strong resistance to neutralize their actions, while a score of 6 defined a strong attitude to neutralize their action.

The mean score for frequency of students' neutralization behavior, with a range of 15 to 90 , was 81.06 for students enrolled in institutions with mandatory ethics course in their curriculum and 75.85 for students enrolled in institutions without mandatory ethics courses in their curriculum. The data indicated that as a group, students enrolled in institutions with mandatory ethics course demonstrate a tendency to resist neutralization behavior while students enrolled in institutions without mandatory ethics course demonstrated only a slight tendency to resist neutralization behavior.

Table 18 reports the number of responses, the mean frequency of students' attitude toward neutralization behavior, the standard deviation, and the number of items. Table 19 represents the results of the $t$-test. Table 20 reports the frequency of students' specific behavior of neutralization. 
Table 18. Means and Standard Deviation for Neutralization Behavior

\begin{tabular}{lcccc}
\hline School with Ethics Course & N & M & SD & Number of Items \\
\hline Normalization Behavior & 84 & 81.06 & 9.71 & 16 \\
\hline Valid N & 84 & & & \\
\hline School without Ethics Course & N & M & SD & Number of Items \\
\hline Normalization Behavior & 71 & 75.85 & 13.29 & 16 \\
\hline Valid N & 71 & & & \\
\hline
\end{tabular}

Table 19. t-test Neutralization

\begin{tabular}{lcccccccc}
\hline School Code & $\mathrm{N}$ & $\mathrm{M}$ & $\mathrm{SD}$ & $\mathrm{SDE}$ & $\mathrm{T}$ & $\mathrm{df}$ & $\rho$ & Mean Difference \\
\hline Ethic Course & 84 & 81.06 & 9.71 & 1.02 & 2.82 & 153 & 0.04 & 5.21 \\
No Ethic Course & 71 & 75.85 & 13.29 & 1.63 & & & & \\
\hline
\end{tabular}

Fourteen questions were selected to measure the participants' normalization of deviance behavior, survey responses were scored using a six point Likert scale ranging from 1) Strongly disagree, 2) Disagree, 3) Slightly disagree, 4) Slightly agree, 5) Agree, to 6) Strongly agree. A score of one defined a strong inclination to normalization of deviance while a score of 6 defined a resistance to normalization of deviance.

The mean score for frequency of students' attitude toward normalization of deviance, with a range of 63 to 90 was 79.05 for students enrolled in institutions with a mandatory ethics course in their curriculum. The mean score for frequency of students' normalization of deviance, with a range of 63 to 90 was 76.50 for students enrolled in institutions without a mandatory ethics course in their curriculum. The data indicated that as a group, students enrolled in institutions with a mandatory ethics course tend to follow the norms and repel normalization of deviance. Students enrolled in institutions without a mandatory ethics course also tends to follow the norms with a slight tendency towards the direction of normalization of deviance. 
Table 20. Frequency students' specific behavior of neutralization

\begin{tabular}{|c|c|c|c|c|c|c|c|c|}
\hline \multirow[b]{3}{*}{$\begin{array}{l}\text { Cheating on a test is better than failing } \\
\text { the course }\end{array}$} & \multicolumn{4}{|c|}{ School with Ethics Course } & \multicolumn{4}{|c|}{ School without Ethics Course } \\
\hline & STD & $\mathrm{D}+\mathrm{SLD}$ & $\begin{array}{c}\mathrm{A}+\mathrm{SL} \\
\mathrm{A}\end{array}$ & STA & STD & $\begin{array}{c}\mathrm{D}+\mathrm{SL} \\
\mathrm{D}\end{array}$ & $\begin{array}{c}\mathrm{A}+\mathrm{SL} \\
\mathrm{A}\end{array}$ & STA \\
\hline & $45.2 \%$ & $47.6 \%$ & $7.2 \%$ & $0.0 \%$ & $35.2 \%$ & $39.5 \%$ & $23.9 \%$ & $1.4 \%$ \\
\hline $\begin{array}{l}\text { Cheating is okay if the instructor gives } \\
\text { unreasonably difficult assignments or } \\
\text { tests }\end{array}$ & $45.2 \%$ & $48.8 \%$ & $6.0 \%$ & $0.0 \%$ & $32.4 \%$ & $57.8 \%$ & $9.8 \%$ & $0.0 \%$ \\
\hline $\begin{array}{l}\text { Cheating on a test is okay if the course } \\
\text { material is too difficult to understand }\end{array}$ & $48.8 \%$ & $48.8 \%$ & $2.4 \%$ & $0.0 \%$ & $33.8 \%$ & $62.0 \%$ & $4.2 \%$ & $0.0 \%$ \\
\hline $\begin{array}{l}\text { It is okay if you can't study or prepare } \\
\text { for a simulation session assignment } \\
\text { because you have other commitments. }\end{array}$ & $15.5 \%$ & $55.9 \%$ & $28.6 \%$ & $0.0 \%$ & $9.9 \%$ & $54.9 \%$ & $33.8 \%$ & $1.4 \%$ \\
\hline $\begin{array}{l}\text { Lying to passengers is okay if it does } \\
\text { not cause them harm. }\end{array}$ & $31.0 \%$ & $39.3 \%$ & $28.5 \%$ & $1.2 \%$ & $23.9 \%$ & $49.3 \%$ & $24.0 \%$ & $2.8 \%$ \\
\hline $\begin{array}{l}\text { Cheating on a test is okay if everyone } \\
\text { else in the class seems to be doing it. }\end{array}$ & $40.5 \%$ & $58.3 \%$ & $1.2 \%$ & $0.0 \%$ & $33.8 \%$ & $53.5 \%$ & $9.8 \%$ & $2.9 \%$ \\
\hline $\begin{array}{l}\text { Cheating on a test is okay if the people } \\
\text { sitting around me make no attempt to } \\
\text { cover their answers. }\end{array}$ & $58.3 \%$ & 39.3\% & $2.4 \%$ & $0.0 \%$ & $43.7 \%$ & $47.9 \%$ & $5.6 \%$ & $2.8 \%$ \\
\hline $\begin{array}{l}\text { Cheating is okay if a good friend, at } \\
\text { risk of failing the course, asks for my } \\
\text { help. }\end{array}$ & $38.1 \%$ & $47.6 \%$ & $14.3 \%$ & $0.0 \%$ & $31.0 \%$ & $46.5 \%$ & $19.7 \%$ & $2.8 \%$ \\
\hline $\begin{array}{l}\text { Cheating on a test is okay because } \\
\text { students should stick together and help } \\
\text { one another. }\end{array}$ & $42.9 \%$ & $52.4 \%$ & $2.4 \%$ & $2.3 \%$ & $38.0 \%$ & $49.3 \%$ & $11.3 \%$ & $1.4 \%$ \\
\hline $\begin{array}{l}\text { Copying a paper from another source } \\
\text { is okay if too much coursework is } \\
\text { assigned. }\end{array}$ & $52.3 \%$ & $46.5 \%$ & $1.2 \%$ & $0.0 \%$ & $38.0 \%$ & $52.1 \%$ & $8.4 \%$ & $1.5 \%$ \\
\hline $\begin{array}{l}\text { Cheating on a test is okay because it } \\
\text { does not hurt anyone. }\end{array}$ & $58.4 \%$ & $39.2 \%$ & $1.2 \%$ & $1.2 \%$ & $40.8 \%$ & $53.5 \%$ & $5.7 \%$ & $0.0 \%$ \\
\hline $\begin{array}{l}\text { It is okay to make up an excuse to not } \\
\text { take a test if you have not had time to } \\
\text { study for the test. }\end{array}$ & $45.2 \%$ & $50.0 \%$ & $3.6 \%$ & $1.2 \%$ & $32.4 \%$ & $52.1 \%$ & $12.7 \%$ & $2.8 \%$ \\
\hline $\begin{array}{l}\text { Cheating on a test is okay to pass the } \\
\text { course. }\end{array}$ & $47.6 \%$ & $48.8 \%$ & $3.6 \%$ & $0.0 \%$ & $36.6 \%$ & $49.3 \%$ & $12.7 \%$ & $1.4 \%$ \\
\hline $\begin{array}{l}\text { Student pilots would not cheat on a test } \\
\text { if there was not so much pressured to } \\
\text { succeed in the program. }\end{array}$ & $11.9 \%$ & $47.7 \%$ & $33.3 \%$ & $7.1 \%$ & $16.9 \%$ & $42.2 \%$ & $33.8 \%$ & $7.1 \%$ \\
\hline $\begin{array}{l}\text { It is not terrible if you cheat on a test if } \\
\text { you have studied hard for the test. }\end{array}$ & $38.1 \%$ & $52.4 \%$ & $8.3 \%$ & $1.2 \%$ & $29.6 \%$ & $57.7 \%$ & $11.2 \%$ & $1.5 \%$ \\
\hline $\begin{array}{l}\text { Cheating or plagiarizing a paper is } \\
\text { okay if it is important for me to } \\
\text { succeed in the aviation program and be } \\
\text { considered successful. }\end{array}$ & $54.8 \%$ & $45.2 \%$ & $0.0 \%$ & $0.0 \%$ & $42.3 \%$ & $49.3 \%$ & $7.0 \%$ & $1.4 \%$ \\
\hline
\end{tabular}

STD= Strongly Disagree, $\mathrm{D}=$ Disagree, $\mathrm{SLD}=$ Slightly Disagree SLA= Slightly agree, $\mathrm{A}=$ Agree, $\mathrm{STA}=$

Strongly agree. 
Table 21 reports the number of responses, the mean frequency of students' attitude toward normalization of deviance, the standard deviation, and the number of items. Table 22 reports the result of the $t$-test. Table 23 reports the frequency of students' specific behavior of normalization of deviance.

Table 21. Mean and Standard Deviation for Normalization of Deviance

\begin{tabular}{lccc}
\hline School with Ethics Course & N & M & SD \\
\hline Normalization of Deviance & 78 & 79.05 & 7.50 \\
\hline Valid N & 78 & & \\
\hline School without Ethics Course & N & M & SD \\
\hline Normalization of Deviance & 65 & 76.50 & 8.18 \\
\hline Valid N & 65 & & \\
\hline
\end{tabular}

Table 22: t-test Normalization of Deviance

\begin{tabular}{ccccccccc}
\hline School Code & $\mathrm{N}$ & $\mathrm{M}$ & $\mathrm{SD}$ & $\mathrm{SDE}$ & $\mathrm{t}$ & $\mathrm{df}$ & $\rho$ & Mean Difference \\
\hline Ethic Course & 78 & 79.05 & 7.50 & 0.84 & 1.86 & 141 & 0.03 & 2.54 \\
No Ethic & 65 & 76.51 & 8.82 & 1.13 & & & & \\
\hline
\end{tabular}


Table 23: Frequency of students' specific behavior on Normalization of Deviance

Student pilots are responsible for Aeronautical Decision Making and the successful and safe competition of the flight

It is essential for student pilots to be familiar with the Student Academic Code of Conduct. Student pilots must always do what is right

Adherence to the pilots' Code of Ethics is important to the aviation profession.

It is essential for student pilots to be familiar with the Pilot Code of Ethics.

Adherence to the pilots' Code of Ethics is important to me personally.

Adherence to the pilot's Code of Ethics is important to me professionally.

Professional pilots are accountable for their own professional practice.

Professional pilots must continue to grow professionally and technically after completion of the Pilots' Program and their initial training.

Professional pilots must maintain their competency in the aviation industry.

Professional pilots must always embrace the values of the pilots' profession.

Professional pilots have to integrate professional values with their own personal values.

Professional pilots must always be honest with passengers, crew members, and fellow pilots.

Professional pilots are responsible for good and sound aeronautical decision making and judgment.

\begin{tabular}{|c|c|c|c|c|c|c|c|}
\hline \multicolumn{4}{|c|}{ School with Ethics Course } & \multicolumn{4}{|c|}{ School without Ethics Course } \\
\hline STD & $\begin{array}{c}\mathrm{D}+\mathrm{SL} \\
\mathrm{D} \\
\end{array}$ & $\begin{array}{c}\mathrm{A}+\mathrm{SL} \\
\mathrm{A}\end{array}$ & STA & STD & $\begin{array}{c}\mathrm{D}+\mathrm{SL} \\
\mathrm{D} \\
\end{array}$ & $\begin{array}{c}\mathrm{A}+\mathrm{SL} \\
\mathrm{A}\end{array}$ & STA \\
\hline $1.1 \%$ & $8.4 \%$ & $54.8 \%$ & $35.7 \%$ & $2.9 \%$ & $5.6 \%$ & $50.7 \%$ & $40.8 \%$ \\
\hline $0.0 \%$ & $4.7 \%$ & $52.4 \%$ & $42.9 \%$ & $0.0 \%$ & $5.7 \%$ & $62.9 \%$ & $31.4 \%$ \\
\hline $0.0 \%$ & $11.9 \%$ & $42.9 \%$ & $45.2 \%$ & $0.0 \%$ & $11.2 \%$ & $40.9 \%$ & $47.9 \%$ \\
\hline $0.0 \%$ & $1.2 \%$ & $50.6 \%$ & $48.2 \%$ & $2.9 \%$ & $7.0 \%$ & $38.0 \%$ & $52.1 \%$ \\
\hline $1.2 \%$ & $6.0 \%$ & $49.4 \%$ & $43.4 \%$ & $1.4 \%$ & $4.2 \%$ & $52.1 \%$ & $42.3 \%$ \\
\hline $0.0 \%$ & $4.8 \%$ & $55.4 \%$ & $39.8 \%$ & $1.4 \%$ & $5.8 \%$ & $59.4 \%$ & $33.4 \%$ \\
\hline $0.0 \%$ & $3.6 \%$ & $47.6 \%$ & $48.8 \%$ & $1.5 \%$ & $10.1 \%$ & $52.2 \%$ & $36.2 \%$ \\
\hline $0.0 \%$ & $3.6 \%$ & $47.6 \%$ & $48.8 \%$ & $1.4 \%$ & $7.0 \%$ & $47.9 \%$ & $43.7 \%$ \\
\hline $2.4 \%$ & $0.0 \%$ & $36.1 \%$ & $61.5 \%$ & $0.0 \%$ & $5.7 \%$ & $38.0 \%$ & $56.3 \%$ \\
\hline $0.0 \%$ & $2.4 \%$ & $34.9 \%$ & $62.7 \%$ & $0.0 \%$ & $5.8 \%$ & $37.1 \%$ & $57.1 \%$ \\
\hline $0.0 \%$ & $1.1 \%$ & $59.1 \%$ & $39.8 \%$ & $0.0 \%$ & $10.0 \%$ & $50.0 \%$ & $40.0 \%$ \\
\hline $0.0 \%$ & $3.6 \%$ & $64.3 \%$ & $32.1 \%$ & $0.0 \%$ & $17.0 \%$ & $59.1 \%$ & $23.9 \%$ \\
\hline $0.0 \%$ & $9.5 \%$ & $52.4 \%$ & $38.1 \%$ & $1.4 \%$ & $8.4 \%$ & $42.3 \%$ & $47.9 \%$ \\
\hline $0.0 \%$ & $2.4 \%$ & $34.5 \%$ & $63.1 \%$ & $1.4 \%$ & $4.3 \%$ & $30.0 \%$ & $64.3 \%$ \\
\hline
\end{tabular}

$\mathrm{STD}=$ Strongly Disagree, $\mathrm{D}=$ Disagree, $\mathrm{SLD}=$ Slightly Disagree SLA= Slightly agree, $\mathrm{A}=$ Agree, STA= Strongly agree 


\section{DISCUSSION}

Ethics, academic conduct and professional conduct are not new subjects, and they have long been recognized as necessary inclusions in professional pilot curriculum across the United States. In recent times, however, increased emphasis has been placed on these issues due partly to fatal airline accidents. On February 12, 2009 a DHC-8-400 aircraft operating as Continental Connection Flight 3407 crashed short of the runway in Buffalo, N.Y. killing all 50 people on board. As a result of the investigation, the U.S. Congress recommended a formal code of ethics for professional pilots, among other recommendations. The National Transportation Safety Board indicated the probable cause of the accident as,

"The National Transportation Safety Board determines that the probable cause of this accident was the captain's inappropriate response to the activation of the stick shaker, which led to an aerodynamic stall from which the airplane did not recover. Contributing to the accident were (1) the flight crew's failure to monitor airspeed in relation to the rising position of the low speed cue, (2) the flight crew's failure to adhere to sterile cockpit procedures, (3) the captain's failure to effectively manage the flight, and (4) Colgan Air's inadequate procedures for airspeed selection and management during approaches in icing conditions.

The safety issues discussed in this report focus on strategies to prevent flight crew monitoring failures, pilot professionalism, fatigue, remedial training, pilot training records, airspeed selection procedures, stall training, Federal Aviation Administration (FAA) oversight, flight operational quality assurance programs, use of personal portable electronic devices on the flight deck, the FAA's use of safety alerts for operators to transmit safety-critical information, and weather information provided to pilots. Safety recommendations concerning these issues are addressed to the FAA." (National Transportation Safety Board, 2010, p. 155)

This study indicates that a simple ethics courses will not alter student behavior toward academic or ethical conduct. No significant difference was found between these two groups of students in academic conduct, academic dishonesty beliefs, ethical conduct, and ethical beliefs. However, there was a significant difference in neutralization behavior. Students enrolled in ethics course accepted the responsibility for their actions and classified such actions as improper.

Students in curriculums without ethics course tend to shift the blame elsewhere, justifying their actions in their quest of acceptance from society. One of the basic characteristics of students' sub-culture, or the sub-culture of individuals exhibiting deviant behavior, is the possession of a set of values contradicting the set of values held by law-abiding students (Sutherland, 1955). Ethics courses structured to change the students' conception and presenting the students with cases studies of ethical decision making have been proven to be effective in many business schools. Conceptual Change Theory applied in ethics courses presents the students with alternatives to their old beliefs or naïve psychology, challenging the students to re-evaluate their decision-making process.

A significant difference was also found in normalization of deviance. Students enrolled in a course of study without an ethics course tended to deviate from the norms ruling the general student body, and repeated deviations caused them to justify such behavior. This behavior is a byproduct of the neutralization behavior. Therefore, if students' neutralization behavior can be controlled the normalization of deviance should be proportionally reduced. 


\section{RECOMMENDATIONS}

The need for ethics course in the professional pilot curriculum has been debated for over a decade, yet only few universities has implemented an aviation ethics course as part of the curriculum. This study clearly demonstrated that students who participated in ethics courses were less likely to neutralize their misbehavior and were also less likely to deviate from the norms. Therefore, a recommendation can be made to implement an aviation ethics course as part of the professional pilot curriculum for the benefit of safety.

The literature showed that Ethics Across the Curriculum (EAC) can be used for supporting the standalone ethics courses and also for program of study where the addition of a course it is impractical for various reason. EAC was reported to work very well in institutions with faculty support for ethics courses. It is recommended that institutions that have the ability to implement stand-alone ethics course in their curriculum gain support of the faculty and considered implementation of EAC as a support for the course and as a reinforcement for the students.

As this study shows, students in institutions with mandatory ethics course score higher on neutralization behavior and Normalization of Deviance. However, their conduct and beliefs were similar to those of the students without mandatory ethics course. Conceptual Change Theory is used to work with students' misconceptions, the belief that is held contrary to known evidence. These misconceptions are mostly formed as the result of limited personal experiences, observations, or social interactions and inaccurate prior instructions. Many researchers refer to misconception as naïve psychological science to indicate that an individual will acquire these ideas in a primitive way through trial-and-error. Conceptual change learning refers to the type of learning that occurs when the learner is introduced to new knowledge that is in conflict with earlier knowledge and must reorganize presented schemata and change formerly held ideas. This study has uncovered the need for Conceptual Change Theory structure in ethics courses. It is therefore recommended that Conceptual Change Theory be used in already implemented aviation ethics courses and to considered this theory for future ethics courses development.

\section{RECOMMENDATIONS FOR FUTURE STUDIES}

A study in which the researcher will randomly select two similar groups of students and administer a pre-test at the start of the semester. The researcher will then administer one group with a treatment, (an ethics course) while the second group will have no treatment. A post-test at the end of the semester will be administered to compare learned behavior and differences between the two groups. This study will give the researcher a clear indication of the effect of ethics course using conceptual change theory.

The ideal study to measure the effect of ethics course in a professional pilot's curriculum will be one where the researcher will randomly survey airline pilots. The survey will include pilots who studied in universities with mandatory ethics course and without ethics course. The survey will then measure the

pilots' ethical conduct and beliefs. This will allow the researcher to predict the effect of ethics course with a higher degree of certainty. 


\section{REFERENCES}

Antion, D. L., \& Michael, W. B. (1983). Short-term predictive validity of demographic, affective, personal, and cognitive variables in relation to 2 criterion measures of cheating behavior. Educational and Psychological Measurement 43(2): 467-483.

Aronfreed, J. (1968). Conduct and Conscience. New York, N.Y: Academic Press.

Baird, J. S. (1980). Current trends in college cheating. Psychology in the Schools 17(4): 515-522.

Bandura, A. (1986). Social Foundations of Thought and Action. Englewood Cliffs, N.J: Prentice-Hall.

Ben-Jacob, M. G. (2005). Integrating Computer Ethics across the Curriculum: A Case Study. Educational Technology \&Society, 8 (4), 198-204.

Bowers, W. J. (1964). Student Dishonesty and Its Control in College. New York: Bureau of Applied Social Research, Columbia University.

Cavaliere, F.J., Mulvaney, T.P., \& Swerdlow, M.R. (2010). Teaching Business Ethics After the Financial Meltdown: Is it Time for Ethics with a Sermon? Education Chula Vista. 131(1), 3-8.

Chinn, C.A., \& Brewer, W.F. (1993). The role of anomalous data in knowledge acquisition: A theoretical framework and implications for science instruction. Review of Educational Research.63, 1-49.

Christensen, S.L., \& Kohls, J. (2003). Ethical Decision Making in Times of Organizational Crises. Business and Society. 42, 328-358.

Churchill, L.R. (1982). The Teaching of Ethics and Moral Values in Teaching: Some Contemporary Confusion. The Journal of Higher Education.53(3), 296-306.

Cragg, W. (1997).Teaching Business Ethics: The role of Ethics in Business and in Business Education. Journal of Business Ethics.16, 231-245.

Dole, J.A., \& Sinatra, G.M. (1998). Re-conceptualizing change in the cognitive construction of knowledge. Educational Psychologist.33(2/3), 109-128.

Federal Aviation Administration; 14 C.F.R. § 61. (2000, January 21). Washington, DC: U.S. Government Printing Office.

Federal Aviation Administration; 14 C.F.R. § 141. (2000, January 21). Washington, DC: U.S. Government Printing Office.

Federal Aviation Administration. (2008, August 14). FAA Seeks Penalties Against American Airlines for Deferred Maintenance, Other Violations. Retrieved December 04, 2009, from http://www.faa.gov/news/press_releases/news_story.cfm?newsId=10269

Goolsby, J. R., \& Hunt, S.D. (1992). Cognitive moral development and marketing. Journal of Marketing. 56, 55-68. 
Gundersen, D.E., Capozzoli, E.A., \& Rajamma, R.K. (2008). Learned Ethical Behavior: An Academic Prospective. Journal of Education for Business. 83(6), 315-325.

Haines, V. J., Diekhoff, G. M., LaBeff, E. E. \& Clark, R. E. (1986). College cheating: Immaturity, lack of commitment and the neutralizing attitude. Research in Higher Education 25(4), 342-354.

Harris, H. (2008). Promoting Ethical Reflection in the Teaching of Business Ethics. Business Ethics: A European Review. 17(4), 379-390.

Hartshorne, H., \& May, M. A. (1928). Studies in deceit. New York: Macmillan.

Hetherington, E.W., \& Feldman, S.E. (1964). College cheating as a function of subject and situational variables. Journal of Educational Psychology. 55(4), 212-218.

Irwin, T. (1995). Plato’s Ethics. New York, N.Y: Oxford University Press.

James, H. S., Jr. (2000). Reinforcing ethical decision making through organizational structure. Journal of Business Ethics, 28(1), 43-58.

Jenning, M.M. (1999). What’s happening in business schools? The Public interest: Fall 1999, 137.

Kirkvliet, J. (1994). Cheating by economics students: A comparison of survey results. Journal of Economics Education 25(Spring), 121-133.

Kohlberg, L. (1969). Stage and sequence: The cognitive developmental approach to socialization. In D. Goslin (Ed.), Handbook of socialization theory and research (347-480). Chicago: Rand McNally.

Kohlberg, L. (1974). Education, Moral Development and Faith. Journal of Moral Education,4 (1): 5-16

Kowalski, P., \& Taylor, A.K. (2004). Ability and Critical Thinking as Predictors of Change in Students’ Psychological Misconceptions. Journal of Instructional Psychology.31(4).

Leming, J.S. (1980). Cheating behavior, subject variables, and components of the internal-external scale under higher and low risk conditions. Journal of Educational Research, 74(2), 83-87.

Lin, C.S. \& Wen, L.M. (2007). Academic dishonesty in higher education-a nationwide study in Taiwan. Higher Education, 54, 85-97.

Lipson, A. \& McGavern, N. (1993). Undergraduate academic dishonesty: A comparison of student, faculty and teaching assistant attitudes and experiences. Paper presented at the annual meeting of the Association for Institutional Research, Chicago, IL.

Lupton, R.A., Chapman, K.J., \& Weiss, J.E. (2000). A Cross-National Exploration of Business Students' Attitude, Perceptions, and Tendencies Toward Academic Dishonesty. Journal of Education for Business 75(4), 231-235.

Magnus, J.R., Polterovich, V.M., Danilov, D.L., \& Savvateev, A.V. (2002). Tolerance of cheating: An analysis across countries. Journal of Economic Education, 33(2) 125-135.

Matchett, N.J. (2008), Ethics Across the Curriculum. New Dictionary for Higher Education, 142 (Summer 2008), 25-38. 
McCabe, D.L. \& Trevino, L.K. (1993). Academic dishonesty: Honor codes and other contextual influences. Journal of Higher Education 65(5), 520-538.

McCabe, D.L. \& Trevino, L.K. (1997). Individual and contextual influences on academic dishonesty: A multi-campus investigation. Research in Higher Education, 38(3), 379-396.

National Transportation Safety Board. (2010). Loss of Control on Approach, Colgan Air, Inc. Operating as Continental Connection Flight 3407. (NTSB/AAR-10/01/PB2010-910401). Washington, D.C.:NTSB

Northam, G., \& Diels, E. (2007). Ethical Decision Making by Certified Flight Instructors. Proceedings of the Third Safety Across High Consequence Industries Conference. St. Louis: Saint Louis University.

Oderman, D.B. (2002). Ethics Education in University Aviation Management Programs in the US: Part One-The Need. Journal of air Transportation, 7(3).

Rest, J. (1979). Development in Judging Moral Issues (1 $1^{\text {st }}$. ed). Minneapolis, MN: University of Minnesota Press.

Rest, J., \& Narvaez, D. (1994). Moral Development in the Professions. Hillsdale, N.J: Lawrence Erlbaum Associates.

Roskens, R.W., \& Dizney, H.F. (1966). A study of unethical academic behavior in higher school and college. Journal of Educational Research 59(5): 231-234.

Southwest to pay fine of \$ 7.5 million. (2009, March 3). Los Angeles Times, p. B6.

Sutherland, E. H. (1955). Principles of Criminology, revised by D. R. Cressey, Chicago: Lippincott.

Sykes, G.M., Matza, D. (1957). Techniques of neutralization: A theory of delinquency. American Sociological Review, 22(6), 664-670.

Taylor, A.K., \& Kowalski, P. (2004). Naïve Psychology Science: The Prevalence, Strength, and Sources of Misconception. The Psychological Record.54 (1), 15-25.

Vandehey, M.A., Diekhoff, G.M. \& LaBeff, E.E. (2007). College Cheating: A Twenty-Year Follow-Up and the Addition of an Honor Code. Journal of College Student Development 48(4): 468-480.

Ward, D. A. \& Beck, W. L. (1990). Gender and dishonesty. The Journal of Social Psychology 130(3): 333-339. 